\title{
Optimal management of pediatric hepatitis $C$ infection: a review
}

This article was published in the following Dove Press journal:

Pediatric Health, Medicine and Therapeutics

2I November 2014

Number of times this article has been viewed

\section{Amanda Fifi \\ Andrea Barreto Aymin Delgado-Borrego \\ Division of Pediatric Gastroenterology, Hepatology and Nutrition, University of Miami, Miller School of Medicine, Miami, FL, USA}

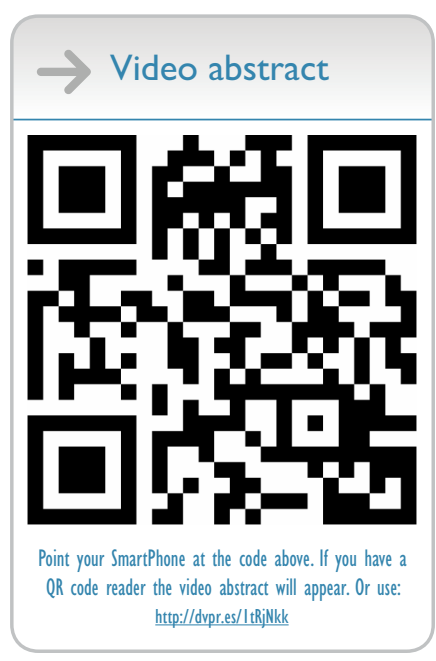

Correspondence: Aymin DelgadoBorrego

Pediatric Clinical Research and Pediatric Gastroenterology, Hepatology and Nutrition, University of Miami Miller School of Medicine, Batchelor Children's Research Institute, I580 NW IOth Avenue, Room 523, Miami, FL 33136, USA

Tel + I 3052433559

Email adelgado5@med.miami.edu

\begin{abstract}
Hepatitis $\mathrm{C}$ virus (HCV) is a blood-borne infection and one of the most important global health problems at present. This infection is the most common cause of liver transplantation in the USA, and is associated with significant morbidity, mortality, and high health care costs. Although children represent a fraction of the total infected population, pediatric HCV is a condition with an important health impact. The natural history of pediatric HCV is not fully understood. While most young patients are characterized by having mild liver disease during childhood, many have moderate and some have advanced fibrosis even early on in life. The factors that determine these differences have not been established. There have been significant advances with regard to treatment of $\mathrm{HCV}$ infection among adults over the last few years. Management of affected children has also improved and is expected to achieve a sustained virologic response in the majority of patients treated in the near future. This review discusses the epidemiology and present knowledge about the natural history of pediatric HCV infection, focuses on current management options, and provides a brief overview of future therapies.
\end{abstract}

Keywords: hepatitis $\mathrm{C}$ virus, children, management

\section{Epidemiology and public health}

Hepatitis $\mathrm{C}$ virus infection (HCV) infection is a global health problem and is the most common blood-borne infection in the USA. Globally, approximately 185 million people are infected with HCV. ${ }^{1}$ In the USA, 2.7-3.9 million people (adults and children) have chronic HCV infection. ${ }^{2}$ According to the Third National Health and Nutrition Examination Survey, $0.2 \%$ of US children aged 6-11 years and $0.4 \%$ of adolescents aged 12-19 years were HCV antibody-positive. ${ }^{3}$ In terms of actual cases, Jhaveri et al projected that, in the USA, there will be approximately 30,248-49,496 children chronically infected with HCV between 2007 and 2017..$^{4}$ At present, approximately $60 \%-90 \%$ of cases of hepatitis $\mathrm{C}$ infection in children are the result of perinatal transmission, with the remaining cases resulting from intravenous drug use, sharing of intranasal straws, tattooing, and body piercings. ${ }^{5,6}$ The overall risk of maternalinfant transmission ranges from $5 \%$ to $10 \%,{ }^{7-9}$ and maternal coinfection with human immunodeficiency virus (HIV) approximately doubles the vertical spread rate. ${ }^{10}$ However, according to the Institute of Medicine, hepatitis $\mathrm{C}$ infection remains largely underdiagnosed, with at least $50 \%$ of infected subjects unaware of their HCV status. ${ }^{2}$ An even larger percentage of infected children may remain unidentified. ${ }^{11}$ Thus, the true prevalence and incidence of this condition in the young remain unknown, and the impact of pediatric infection on the overall hepatitis $\mathrm{C}$ burden has not been evaluated. 
Hepatitis $\mathrm{C}$ is associated with significant morbidity and health care cost. Although HCV is thought to induce relatively mild disease, children can present with more advanced clinical manifestations. There have been several case reports of hepatocellular carcinoma among children and young adults who acquired $\mathrm{HCV}$ infection during childhood. ${ }^{12}$ In addition, the worldwide financial burden of $\mathrm{HCV}$ infection is high, with projected direct medical costs of $\$ 10.7$ billion from 2010 to $2019,,^{13,14}$ and \$119-\$336 million in children over the next decade. ${ }^{4}$ Adequate surveillance and linkage to medical care of children at risk for this infection are necessary to reduce morbidity and the associated cost.

In a consensus report issued in January 2010 by the Institute of Medicine, it was noted that there is a lack of knowledge and awareness about chronic viral hepatitis. In addition, there is insufficient understanding about the extent and seriousness of this public health problem, with inadequate public resources being allocated to prevention, control, and surveillance programs. ${ }^{2}$ Based on this report, increased knowledge and awareness about chronic viral hepatitis, improved surveillance, and better integration of services are needed.

\section{Natural history}

The natural history of pediatric HCV has not been clearly established. Currently, perinatal HCV transmission is suggested as the most common mode of infection in children, as evidenced by detectable HCV RNA levels after several weeks of life, proposing that perinatal HCV transmission is more common than intrauterine acquisition. ${ }^{15}$ Regardless of the route of infection, an infant may have detectable anti-HCV antibodies in serum until his/her 18th month of life due to passively transferred antibodies from the mother. ${ }^{6,15}$

The majority of children who acquire HCV develop chronic infection. In a large, multicenter, prospective study of 266 children with vertically acquired HCV infection, $75 \%$ developed chronic infection while $25 \%$ achieved spontaneous viral clearance by 5 years of age, with a median age of clearance of 14.9 months. Positivity of HCV polymerase chain reaction in the first year of life was found to be related to a lower chance of clearance and a higher risk of persistent infection. ${ }^{6}$ The rate of viral clearance in children was $8 \%$ in a large prospective 10-year study, occurring commonly in the first 5 years of follow-up. ${ }^{13,16}$ In a study of 157 children with HCV infection between 1990 and 2001, 28\% cleared infection after 10 years of follow-up. Among neonatal cases, $25 \%$ had spontaneous clearance by 7.3 years. It was found that younger age at follow-up and a normal alanine transaminase (ALT) value favored spontaneous clearance $(P=0.0001) .{ }^{17}$ Children with transfusion-acquired infection have demonstrated higher rates of spontaneous HCV clearance. ${ }^{15}$ A 15 -year study including 504 anti-HCV antibody-positive children enrolled at 12 Italian centers found that 10 years after exposure, $27(7.5 \%)$ of subjects had undetectable viremia (most by the second and third years of life) while $332(92 \%)$ of subjects had persistent HCV. Six of these 332 cases (1.8\%) progressed to decompensated cirrhosis, five being Italian children perinatally infected with genotype 1a (four of the mothers were drug users). ${ }^{16}$ In a multicenter, retrospective, Italian study of anti-HCV antibody-positive and HCV RNA-positive children (aged 1-16 years) observed in 15 pediatric and infectious disease departments between 1990 and 2002, spontaneous sustained HCV RNA clearance occurred in a minority of patients, in most instances during the third year of life..$^{18}$ Spontaneous viral clearance is unlikely beyond 4 years of age. Patients who do not clear the virus within the first years of life will develop chronic hepatitis C. Overall, $80 \%$ is the approximate cumulative probability of development of chronicity, defined as the persistence of HCV RNA for at least 6 months. ${ }^{15,19}$

Pediatric HCV infection is usually asymptomatic or presents with mild nonspecific symptoms. ${ }^{6,15,18}$ Clinical symptoms are observed in approximately $20 \%$ of the infected children, with hepatomegaly being the most frequently observed sign. ${ }^{19,20}$ According to Bortolotti et al, 15.4\% of children had nonspecific, mild, and transient symptoms at the time of diagnosis. Nevertheless, $1.8 \%$ with constantly high ALT levels developed signs and symptoms of advanced liver disease (asthenia, epistaxis, pruritus, ascites, gastrointestinal bleeding).${ }^{16}$ Despite this, infected infants may have normal or intermittently elevated aspartate transaminase and ALT enzymes, particularly in the first 2 years of life. However, ALT elevation does not correlate well with histological severity. ${ }^{6,15,19}$ The highest ALT values were found in children infected with genotype 3 and the lowest in those infected with genotype $2 .{ }^{18}$

Histological manifestations of acute hepatitis $\mathrm{C}$ in children are poorly characterized as this infection is rarely recognized in its acute stage, especially in the young. In contrast, histological abnormalities in chronic hepatitis $\mathrm{C}$ have been better described. There is great variability in the degree of inflammation and fibrosis reported among children with $\mathrm{HCV}$ infection. Badizadegan et al found periportal fibrosis in $78 \%$ and cirrhosis in $8 \%$ of 40 children younger than 18 years of age treated at Boston Children's Hospital. ${ }^{21}$ A study in Cairo, Egypt, found fibrosis in $72.1 \%$ of children 
( $46.5 \%$ with mild and $25.6 \%$ with moderate to severe fibrosis), with a median age for development of fibrosis at 5.5 years. ${ }^{22}$ In a multicenter US trial of pediatric hepatitis $\mathrm{C}$ infection, including 121 children, 17\% had mild, 37\% had moderate, and 3\% had severe inflammation. Significant hepatic fibrosis was present in seven patients and two had cirrhosis. In addition, accumulation of hepatocellular fat was present in $41 \%$ of the biopsy specimens and in $62 \%$ of children infected with HCV genotype $3 .{ }^{23}$ Furthermore, several case reports associate chronic hepatitis $\mathrm{C}$ infection with the development of hepatocellular carcinoma in adolescents and young adults who acquired the infection during childhood. ${ }^{12}$

Although little is known about the impact of HCV infection in children, a recent Australian study showed significantly lower global physical and psychosocial scores in $23 \mathrm{HCV}$-infected children compared with normal controls. ${ }^{6}$ Another study did not find decreased quality of life among infected children in the early stages, but noted a mild decline in neurocognitive functioning and found that caregivers were highly distressed about their children's health. ${ }^{24}$

It is important to note that the majority of children infected with HCV have not been diagnosed. ${ }^{11}$ In addition, $\mathrm{HCV}$ testing in children is most often done at random with no clear association between severity of disease and awareness of HCV status. In other words, children who are diagnosed are not necessarily those with more advanced liver disease as $\mathrm{HCV}$ infection tends to be asymptomatic until development of decompensated cirrhosis. Thus, our understanding of the true natural history of this disease is limited, as published studies have focused on a minority of $\mathrm{HCV}$-infected children (those with diagnosed HCV infection). It is unclear whether the findings thus far represent or may be generalizable to the entire pediatric $\mathrm{HCV}$-infected population.

\section{General management principles Screening of individuals at risk}

The management of pediatric HCV infection should begin with appropriate screening of individuals at risk. According to the Centers for Disease Control and Prevention, individuals at risk for $\mathrm{HCV}$ infection include recipients of blood products or transplanted organs before 1992 or of clotting factors before 1987, and persons born from 1945 through 1965. Risk factors relevant to the pediatric population include infants born to $\mathrm{HCV}$-infected mothers, children or adolescents with a history of injection or intranasal drug use, HIV-infected individuals, patients who have ever received long-term hemodialysis treatment, and those with signs or symptoms of liver disease. ${ }^{25}$ As a result of universal precautions and screening of blood products, the risk of HCV transmission from transplanted organs and blood products has been minimized. Currently, new HCV infections are primarily due to intravenous or nasal drug abuse. In addition, parenteral transmission via tattooing or acupuncture with unsafe materials is also implicated in occasional transmissions. The current consensus considers that the risk of $\mathrm{HCV}$ transmission by sexual intercourse in stable relationships is negligible, ${ }^{26}$ with increased incidence in sexually promiscuous individuals more likely being a marker of other coexistent high-risk behaviors. The Massachusetts Department of Public Health launched a surveillance initiative on cases reported during 2007 and 2009, which revealed continued increases in rates of newly reported $\mathrm{HCV}$ infection among those aged 15-24 years. Of cases with available risk data, injection drug use was the most common risk factor for HCV transmission. These results indicate the need for enhanced surveillance of $\mathrm{HCV}$ infection and intensified hepatitis $\mathrm{C}$ prevention efforts targeting adolescents and young adults. ${ }^{27}$ Several blood tests are performed to test for $\mathrm{HCV}$ infection. These include screening tests for anti-HCV antibody and confirmatory tests using qualitative nucleic acid testing (to detect the presence or absence of virus). ${ }^{28}$

\section{Genotyping tests and quantification of virus}

Genotype testing is commercially available and approved for use in adults, and although not validated at this time, is widely used in pediatrics as well. At least six distinct HCV genotypes (genotypes 1-6) and more than 50 subtypes have been identified. In the USA, the most common HCV genotype is 1 , which is associated with the lowest treatment response rates. Identifying patient genotype is important to establish prognostic risk and to guide management. Once the genotype has been identified, quantitative nucleic acid tests (to detect the amount of nucleic acid from $\mathrm{HCV}$ in blood) are used periodically to assess response to therapy. In addition, identification of the patient genotype has more recently been found to be important given the correlation of the $\mathrm{c}$ allele and the $\mathrm{c} / \mathrm{c}$ genotype in the interferon lambda 3 gene among children who spontaneously cleared $\mathrm{HCV}$ infection. ${ }^{29}$

\section{Assessment of infected children}

The assessment of HCV infection in neonates can be problematic. Testing for anti-HCV antibodies is unreliable before 18 months of age because their detection may be related to passive transfer of maternal antibodies and not active infection. Thus, anti-HCV antibody testing is 
recommended for at-risk infants only after 18 months of age. ${ }^{30}$ Serum HCV RNA tests may be used to confirm viral infection earlier, but nucleic amplification test results within the first 3 months of life are unreliable. ${ }^{31}$

In 2012, the North American Society of Pediatric Gastroenterology, Hepatology and Nutrition (NASPGHAN) published practice guidelines for the diagnosis and management of hepatitis $\mathrm{C}$ infection in infants, children, and adolescents. ${ }^{28}$ It is generally recommended that these children undergo periodic clinical assessments (every 6-12 months) by pediatric gastroenterologists, hepatologists, or other health care providers with adequate training. ${ }^{6-15}$

\section{Counseling and education about HCV infection}

Counseling families of at-risk individuals should begin at the time of testing. Education about HCV infection, including routes of viral spread, natural history, and treatment, as well as signs and symptoms of liver disease should be an ongoing process from the time of diagnosis. This is imperative because the patient and family will need to make informed decisions about their medical care and will have the responsibility for avoiding behaviors that increase the spread of infection, such as sharing toothbrushes, razors, and other personal items potentially contaminated with blood. The use of barrier techniques and hand washing is important in the setting of exposure to the blood of an infected person and is a necessary universal precaution when handling any blood product. In addition, a monogamous partnership with safe sex practices is advisable.

\section{Treatment considerations}

The next important step in the management of hepatitis $\mathrm{C}$ infection is the decision regarding when to initiate medical therapy, which remains a matter of some debate. Children and adults acutely infected with HCV are generally asymptomatic, and infected children often have normal ALT levels. However, children are more likely to spontaneously clear the virus. Given the typically slow histologic progression of liver disease in children, some argue that treatment should be postponed until adulthood. In addition, response rates with currently available antiviral therapies approved by the US Food and Drug Administration (FDA) for the pediatric population remain suboptimal, and are associated with high costs and potential toxicities.

A number of factors, however, support initiation of treatment as early as possible among HCV-infected children older than 3 years of age. Children are likely to be exposed to the adverse effects of HCV for a prolonged period of time; therefore, successful treatment is expected to diminish morbidity in adulthood. ${ }^{32}$ In a retrospective study of Asian patients infected with HCV for more than 60 years, $71 \%$ had cirrhosis on liver biopsy. ${ }^{33}$ Specifically, early treatment may prevent disease progression and avoid potential chronic hepatitis, cirrhosis, liver cancer, and neurocognitive consequences. ${ }^{6}$ In addition, early eradication of $\mathrm{HCV}$ is likely to reduce the social stigma associated with viral infection, a source of significant caregiver stress, ${ }^{24}$ and improve the psychosocial status of patients and their families, who have been found to have high levels of stress. A 2006 study of 70 people infected with hepatitis $\mathrm{C}$ found that this condition had a pervasive impact on quality of life, with universal experience of fear and anxiety about stigma and discrimination. ${ }^{34}$

Children also possess multiple characteristics that make them ideal candidates for treatment. Shorter duration of infection and a lesser degree of hepatic fibrosis are recognized factors associated with improved response to antiviral therapy for HCV. In addition, children have fewer comorbidities than adults, and parental motivation enhances adherence to treatment. Children also tolerate currently available therapies better than adults, with mild flu-like symptoms being the most common complaint, ${ }^{35}$ and in the authors' experience, subcutaneous administration of PEGylated interferon (IFN) is well accepted, with only mild discomfort reported by patients. Although it can be argued that the long-term effects of ribavirin are relatively unknown, its use in pediatric hepatitis $\mathrm{C}$ has been documented in the literature for well over one decade, and it has proven to be safe with side effects that respond to dosage adjustments and usually resolve once treatment is discontinued.

The economic impact of treating children with $\mathrm{HCV}$ infection is substantial. In this regard, treatment at a young age is also advantageous in that the cost of treatment is less than that in adults (less amount of drug used), a reduction of future $\mathrm{HCV}$ liver disease costs is expected, and risk of unemployment and other psychosocial problems associated with hepatitis $\mathrm{C}$ are minimized. ${ }^{6-15}$ It is also expected that eradicating the infection sooner would decrease the risk of transmission to the population at large.

Children younger than 3 years of age are not considered candidates for treatment because IFN has been shown to cause spastic diplegia in this age group. ${ }^{36}$ Once a patient older than 3 years of age is found to be HCV RNA-positive, baseline laboratory studies should be sent and a baseline liver biopsy is recommended (Figure 1). The decision to initiate treatment should be individualized to each patient. 


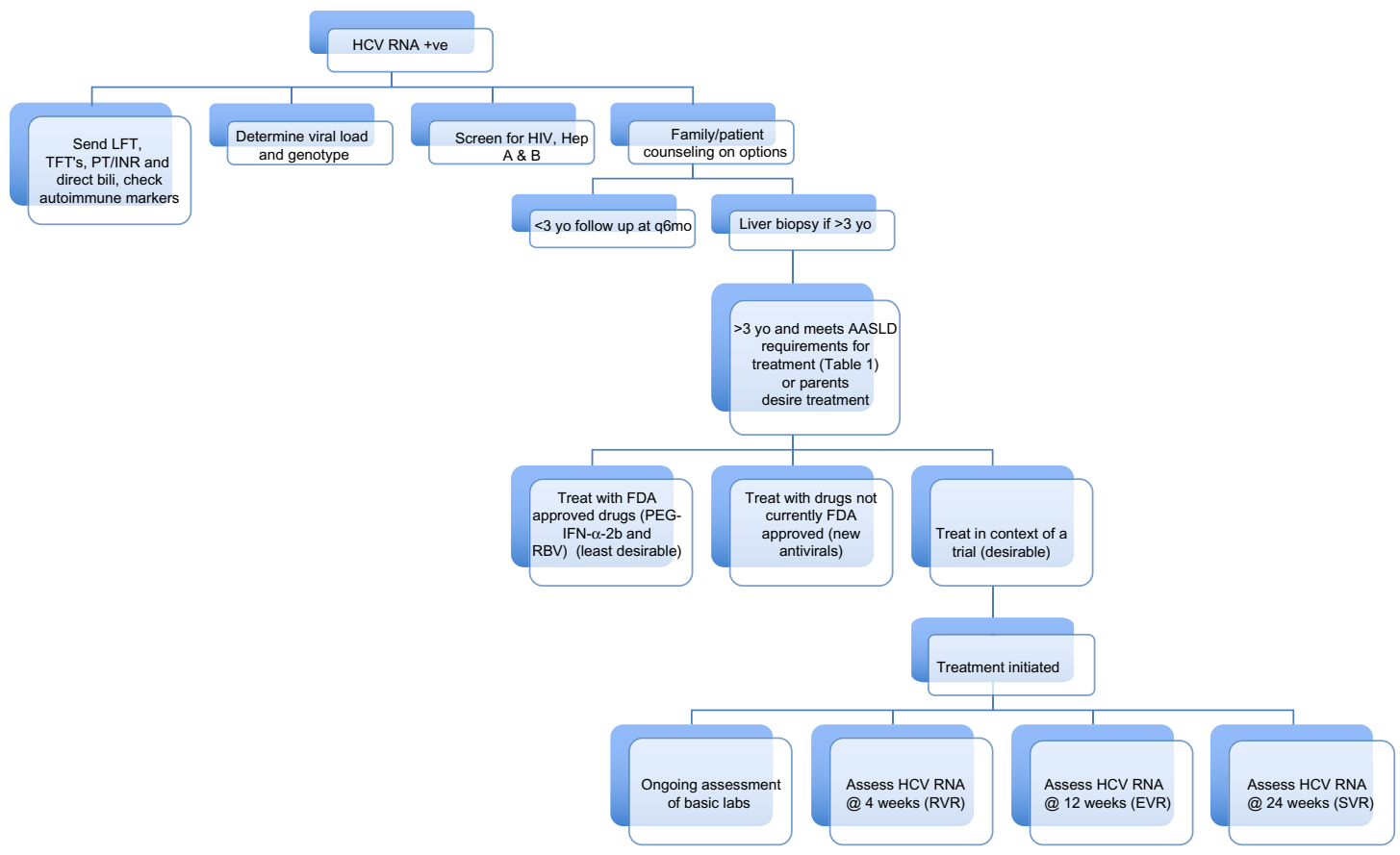

Figure I Algorithm on management of pediatric patients found to be hepatitis $C$ positive.

Abbreviations: LFT, liver function test; TFT, thyroid function test; PEG-IFN, pegylated-interferon; RVR, rapid viral response; EVR, early viral response; SVR, sustained viral response; HCV RNA, Hepatitis C RNA; AASLD, American Association for the Study of Liver Diseases; HIV, human immunodeficiency virus; FDA, US Food and Drug Administration; +ve, positive; PT/INR, prothrombin/international normalized ratio; bili, bilirubin; yo, year old; mo, months; RBV, ribavarin.

Children carrying genotypes 2 and 3 have a higher likelihood of response to current treatments, making early initiation of therapy desirable. However, a watch and wait approach is acceptable in patients with genotypes 1 and 4 who have mild disease on biopsy, anticipating the availability of more efficacious drugs. Some families may opt to treat regardless of genotype and histologic findings on liver biopsy, given the stigma associated with the disease. For children in whom the decision to withhold treatment is made, we recommend follow-up at 6-month intervals to check liver function profile and coagulation studies, assessing for possible disease progression and to update families on newer options for treatment. Ultrasounds can be performed once yearly to look for gross changes in liver echogenicity and to screen for development of hepatocellular carcinoma, although the latter is very rare in the young. Special consideration, prior to initiation of treatment, is advised for certain groups of children and adolescents, including those who are incarcerated or in detention centers, those with a history of substance abuse, and those with psychiatric illness who may have impaired compliance and be at higher risk for certain medication side effects. ${ }^{28}$ Nevertheless, every effort should be made to treat such children and adolescents because they represent highrisk groups for spread of the disease.

Liver biopsy should be performed on diagnosis of HCV infection in children older than 3 years as it is currently the best tool for assessment of hepatic fibrosis. In $121 \mathrm{HCV}$-infected children aged $2-16$ years, inflammation, fibrosis, and steatosis were milder than reported for treatment-naïve adults, yet several children were found to have bridging fibrosis and cirrhosis. ${ }^{23}$ Thus, histologic confirmation of hepatic damage makes the matter of treatment initiation more urgent. However, follow-up biopsies are not advocated at fixed intervals since the rate of progression of liver disease in pediatrics is unclear. In a study of HCV-positive children, $29 \%$ showed an increase in severity of fibrosis over a 5-year period, with adolescents having a higher rate of fibrosis than younger children, indicating an indolent progression of liver disease over the course of several years. ${ }^{37}$ In the authors' opinion, a repeat liver biopsy may be considered if the clinical scenario changes (ie, decline in liver function) or following 3 years from the last biopsy, as information obtained from the repeat liver biopsy may inform the decision to treat. Noninvasive tests such as liver elastography are likely to play an important role in the assessment of progression of fibrosis in hepatitis $\mathrm{C}$ in the future, but have not yet been approved by the FDA for clinical use in pediatrics.

\section{NASPGHAN and AASLD guidelines for management of $\mathrm{HCV}$ infection}

According to the NASPGHAN and the American Association for the Study of Liver Diseases (AASLD) guidelines for management of HCV infection, children aged 3-17 years 
should be considered for treatment using the same criteria as adults..$^{30}$ These criteria are summarized in Table 1.

\section{Screening for other conditions}

Patients found to be HCV-positive should have their immune status for hepatitis A and B (HBV) assessed. A meta-analysis found $\mathrm{HBV} / \mathrm{HCV}$ coinfection to be more strongly associated with hepatocellular carcinoma than either infection alone, suggesting a synergistic effect between the two viruses. ${ }^{38} \mathrm{In}$ addition, it is well established that coinfection with HIV is associated with higher rates of viral persistence, increased viral load, and more rapid progression to end-stage liver disease. ${ }^{28}$ Sustained virologic response has been found to be $15 \%-50 \%$ lower in individuals coinfected with HCV-HIV than in those who are monoinfected. ${ }^{39}$ Establishing HIV status in the HCV-infected patient is important because it will influence not only the natural history but also the response to therapy. Although evidence is lacking with regard to the potential impact of nonalcoholic fatty liver disease on the natural history of hepatitis $\mathrm{C}$ infection, steatosis is often reported in $\mathrm{HCV}$ infection, ${ }^{40}$ and evaluation for this condition should be considered among those at risk, including obese patients and those with a family history of obesity. Finally, alcoholic liver disease is not observed in the young, but

Table I AASLD guidelines for management of HCV infection in patients aged $2-17$ years

Requirements for treatment
Detectable HCV RNA levels
Compensated liver disease (chronic inflammation and significant
fibrosis with serum bilirubin $<1.5 \mathrm{~g} / \mathrm{dL}$, serum albumin $>3.4 \mathrm{~g} / \mathrm{dL}$,
platelets $>75,000 / \mathrm{mm}^{3}$, and without hepatic encephalopathy or ascites)
Willingness to undergo treatment
Acceptable hemoglobin $(13 \mathrm{~g} / \mathrm{dL}$ for men, $12 \mathrm{~g} / \mathrm{dL}$ for women),
neutrophil count ( $\left.1,500 / \mathrm{mm}^{3}\right)$, and creatinine levels ( $\left.1.5 \mathrm{mg} / \mathrm{dL}\right)$
No contraindications to therapy
Contraindications for treatment
Uncontrolled depression
History of solid organ transplant (renal, heart, or lung)
Autoimmune hepatitis or other autoimmune conditions
Pregnancy or sexually active females who refuse contraception
Severe concurrent medical disease
History of hypersensitivity to drugs used to treat HCV
Children younger than 2 years of age
Individualized treatment
Failed prior treatment
Active users of illicit drugs or alcohol (6 months of abstinence
recommended)
Patients with no or mild fibrosis
Setting of acute hepatitis C
Coinfection with HIV
Chronic renal disease
Decompensated cirrhosis, among liver transplant recipients

Abbreviations: AASLD, American Association for the Study of Liver Diseases; $\mathrm{HCV}$, hepatitis $\mathrm{C}$ virus; HIV, human immunodeficiency virus. adolescents should be advised to avoid alcohol to prevent further liver damage.

\section{Antiviral therapy Definitions of virologic response}

The primary goal of therapy is eradication of viremia, namely, a virologic response. Additional goals may include halting the progression of hepatic fibrosis, preventing the development of chronic liver disease, and improving overall quality of life. ${ }^{6}$ Levels of viremia were not found to be associated with disease severity, and levels of viremia can be intermittent and fluctuate in $\sim 18 \%$ of adult patients, being intermittently negative for HCV RNA. ${ }^{41}$ Notably, in the authors' experience and on review of the current literature, there is no evidence in children of intermittent HCV RNA negativity, so this is an area that needs further study in the pediatric population. The primary treatment endpoint is characterized by a sustained virologic response, ie, undetectable serum HCV RNA levels $(<50 \mathrm{IU} / \mathrm{mL}), 24$ weeks after the end of treatment. A rapid virologic response, defined as an undetectable serum $\mathrm{HCV}$ RNA level after 4 weeks of treatment, is now considered the strongest predictor of sustained virologic response, with a positive predictive value of more than $96 \% .^{42} \mathrm{~A}$ study of 105 adults with chronic hepatitis $\mathrm{C}$ found rapid virologic response to be an independent predictor of sustained virologic response, with a sustained virologic response being achieved in $86.7 \%$ of patients who had attained a rapid virologic response compared with a sustained virologic response in only $43.9 \%$ of patients who had not attained a rapid virologic response. ${ }^{43}$ The majority of adult patients who achieve a sustained virologic response also undergo an early virologic response, defined as a $2 \log _{10}(100$-fold $)$ decline in serum HCV RNA levels from pretreatment baseline or undetectable HCV RNA by treatment week 12. Rapid virologic response is yet to supplant early virologic response in determining when to discontinue treatment to avoid potential side effects and decrease cost. The role of rapid virologic response in the treatment of chronic hepatitis $\mathrm{C}$ has been studied in adults for its use in shortening the duration of treatment in patients with HCV genotypes 2 and 3 or as an indicator for both shortened and extended treatment durations among patients with HCV genotype $1 .{ }^{44}$ However, caution should be taken when generalizing findings from adult studies since it is not clear that the same is true in children due to a lack of relevant investigations in the pediatric population ${ }^{45}$ (Table 2).

\section{Interferon, ribavirin, and PEG-IFN}

Early studies focused on IFN monotherapy for the treatment of hepatitis $\mathrm{C}$ in adults as well as children. It later 
Table 2 Definitions of virological response

\begin{tabular}{|c|c|}
\hline $\begin{array}{l}\text { Rapid virological } \\
\text { response }\end{array}$ & $\begin{array}{l}\text { Undetectable serum HCV RNA }(<50 \mathrm{IU} / \mathrm{mL}) \\
\text { after } 4 \text { weeks of treatment }\end{array}$ \\
\hline $\begin{array}{l}\text { Early virological } \\
\text { response }\end{array}$ & $\begin{array}{l}\text { Undetectable or at least a } 2 \text { log decrease in } \\
\text { serum HCV RNA from baseline level after } \\
\text { I } 2 \text { weeks of treatment }\end{array}$ \\
\hline $\begin{array}{l}\text { End of treatment } \\
\text { response }\end{array}$ & $\begin{array}{l}\text { Undetectable serum HCV RNA }(<50 \mathrm{IU} / \mathrm{mL}) \\
\text { at conclusion of treatment }\end{array}$ \\
\hline $\begin{array}{l}\text { Sustained virological } \\
\text { response }\end{array}$ & $\begin{array}{l}\text { Undetectable serum HCV RNA }(<50 \mathrm{IU} / \mathrm{mL}) \\
24 \text { weeks after end of treatment }\end{array}$ \\
\hline Partial response & $\begin{array}{l}\text { Decrease in serum HCV RNA level but still } \\
\text { detectable HCV RNA level at } 24 \text { weeks of } \\
\text { treatment }\end{array}$ \\
\hline Nonresponse & $\begin{array}{l}\text { Detectable serum HCV RNA at } 24 \text { weeks of } \\
\text { treatment without any significant decrease in } \\
\text { serum HCV RNA level }\end{array}$ \\
\hline Relapse & $\begin{array}{l}\text { Detection of serum HCV RNA after an end } \\
\text { of treatment response had been achieved }\end{array}$ \\
\hline
\end{tabular}

Abbreviations: $\mathrm{HCV}$, hepatitis $\mathrm{C}$ virus; RNA, ribonucleic acid.

became clear that addition of ribavirin significantly improved response rates. ${ }^{46,47}$ Similarly, the addition of ribavirin to IFN in the treatment of $\mathrm{HCV}$-infected pediatric patients showed improved response. ${ }^{6,30}$ Addition of polyethylene glycol (PEG) to standard IFN (PEG-IFN) prolongs its half-life, making it possible to reduce the dosing frequency from three times per week to once weekly. In addition, the PEGylation process allows for enhanced plasma levels, resulting in improved viral suppression. There are two commercially available PEGIFN $\alpha$ preparations, ie, PEG-IFN $\alpha-2 a$ and PEG-IFN $\alpha-2 b$, which have a similar efficacy and safety profile. ${ }^{30,48}$

The first randomized, placebo-controlled trial of chronic pediatric HCV treatment in the USA (ie, Peginterferon with or without ribavirin for chronic hepatitis $\mathrm{C}$ in children and adolescents: final results of the Peds-C trial) was recently completed. The results of this study show that $21 \%$ of children treated with PEG-IFN alone in contrast with $53 \%$ of those treated with PEG-IFN in combination with ribavirin achieved a sustained virologic response, demonstrating superiority of the combination over single therapy. ${ }^{49}$ An international multicenter study of 107 children recently published by Wirth et al demonstrated a sustained virologic response in $53 \%$ of patients with genotype $1,93 \%$ of those with genotype $2 / 3$, and $80 \%$ of those with genotype $4 .{ }^{50}$

In 2008, the results of these two trials led to FDA approval of combination therapy with PEG-IFN $\alpha-2 b$ and ribavirin for use in children 3 years of age or older infected with HCV. The established duration of treatment at present is 48 weeks for genotypes 1 and 4 . Adult patients with genotypes 2 and 3 are treated for 24 weeks only, but there are no data to determine whether 24 weeks would be sufficient for treatment of pediatric patients carrying those genotypes. The results of the major studies of treatment of children with $\mathrm{HCV}$ infection are summarized in Table 3 and Figure 2.

\section{Factors associated with response to antiviral treatment}

Factors associated with improved response to antiviral therapy in children include carrying an $\mathrm{HCV}$ genotype other than 1 and low pretreatment HCV RNA (Figure 3). African American race has been associated with diminished response to therapy, but the inclusion of relatively small numbers of African American subjects in published investigations in children precludes definitive conclusions. ${ }^{51}$ Age younger than 12 years was associated with improved response in one study, ${ }^{52}$ but this has not been corroborated by others. The association between being overweight and diminished sustained virologic response has been reported in children, ${ }^{53}$ and represents an important public health concern, given the epidemic proportions of obesity globally. Serum aminotransferase levels have not been associated with response to therapy or disease severity as they can fluctuate greatly. ${ }^{6}$ Single nucleotide polymorphisms in the interleukin 28B gene have been identified as sustained virologic response predictors, so analysis of the interleukin 28B genotype might be used to guide treatment in a subset of patients. ${ }^{54}$ It should be noted that the limited number of subjects included in published pediatric studies precludes a clear understanding of all potential factors that may determine response to antiviral therapy against $\mathrm{HCV}$.

\section{Adverse effects}

The most commonly encountered side effects reported in about $61 \%-100 \%$ of treated children are flu-like symptoms, including pyrexia, fatigue, and headaches, generally attributed to IFN. In addition, gastrointestinal manifestations (nausea, vomiting, and weight loss) and neutropenia may also be observed..$^{50,52,55,56}$ Those adverse effects are minimized by the use of PEG-IFN, which is administered only once weekly. Although agents such as epoetin alpha and granulocyte colony-stimulating factor have been used, they are not recommended because the hematologic side effects of therapy are dose-dependent and reduction of the dose by $20 \%-30 \%$ of PEG-IFN (based on degree of neutropenia) has been used effectively in pediatric treatment trials..$^{50,57}$ More severe and infrequent effects can occur, including depression, irritability, alopecia, and development of thyroid and liver autoantibodies of unclear clinical significance. Reported side effects of IFN are usually reversible with discontinuation of the drug, demonstrating compensatory effects after treatment. ${ }^{50,56}$ 
Table 3 Recent studies on management of hepatitis C comparing sustained viral responses and adverse effects

\begin{tabular}{|c|c|c|c|c|c|c|}
\hline Reference & Entry criteria & Group A & Group B & SVR (A) & SVR (B) & $\begin{array}{l}\text { Adverse } \\
\text { effects }\end{array}$ \\
\hline $\begin{array}{l}\text { Gonzalez-Peralta } \\
\text { et a }{ }^{52}\end{array}$ & $\begin{array}{l}\mathrm{n}=3 \mathrm{I} 2 \\
\text { Age }>3 \text { years } \\
\mathrm{CHC} \\
\mathrm{GI}-4\end{array}$ & $\begin{array}{l}\text { IFN } \alpha-2 b+\text { ribavirin } \\
15 \mathrm{mg} / \mathrm{kg} / \text { day }\end{array}$ & NA & $\begin{array}{l}46 \% \text { (total) } \\
84 \%(G 2 / 3) \\
36 \%(G I)\end{array}$ & NA & $\begin{array}{l}\text { Drug dose } \\
\text { modified (3l\%) } \\
\text { Drug d/c (7\%) }\end{array}$ \\
\hline Jara et a $\left.\right|^{55}$ & $\begin{array}{l}\mathrm{n}=30 \\
\text { Age } 3-16 \text { years } \\
\mathrm{HCV}+\uparrow \mathrm{ALT}\end{array}$ & $\begin{array}{l}\text { IFN } \alpha-2 b \quad \text { I. } 0 \mu \mathrm{g} / \mathrm{kg} / \text { week + } \\
\text { ribavirin } 15 \mathrm{mg} / \mathrm{kg} / \text { day }\end{array}$ & NA & $\begin{array}{l}50 \%(\text { total }) \\
100 \%(G 3) \\
44 \%(G \mid \& 4)\end{array}$ & NA & $\begin{array}{l}\text { Drug dose } \\
\text { modified (23\%) } \\
\text { Drug d/c (10\%) }\end{array}$ \\
\hline Wirth et $\mathrm{a}^{50}$ & $\begin{array}{l}\mathrm{n}=108 \\
\text { Age } 3-17 \text { years } \\
\mathrm{GI}-4\end{array}$ & $\begin{array}{l}\text { IFN } \alpha-2 b \text { I-I.5 } \mu \mathrm{g} / \mathrm{kg} / \text { week + } \\
\text { ribavirin } 15 \mathrm{mg} / \mathrm{kg} / \mathrm{day}\end{array}$ & NA & $\begin{array}{l}70 \% \text { (total) } \\
53 \%(\mathrm{GI}) \\
93 \%(\mathrm{G} 2 \& 3) \\
80 \%(\mathrm{G} 4)\end{array}$ & NA & $\begin{array}{l}\text { Drug dose } \\
\text { modified (25\%) } \\
\text { Drug d/c (I\%) }\end{array}$ \\
\hline Sokal et $\mathrm{al}^{71}$ & $\begin{array}{l}n=65 \\
\text { Age 6-17 years }\end{array}$ & $\begin{array}{l}18 \\
\text { G2\&3 } \\
24 \text { weeks }\end{array}$ & $\begin{array}{l}47 \\
\text { GI, } 4,5,6 \\
48 \text { weeks }\end{array}$ & $89 \%$ (total) & $57 \%$ (total) & $\begin{array}{l}\text { Drug dose } \\
\text { modified (23\%) } \\
\text { Drug d/c (3\%) }\end{array}$ \\
\hline Schwarz et al ${ }^{56}$ & $\begin{array}{l}n=114 \\
\text { Age } 5-17 \text { years }\end{array}$ & $\begin{array}{l}\text { IFN } \alpha-2 b \text { I } 80 \mu g / I .73 \mathrm{~m}^{2} / \\
\text { week + ribavirin } \\
\text { I5 mg/kg twice daily }\end{array}$ & $\begin{array}{l}\text { IFN } \alpha-2 b \quad 180 \mu g / \\
1.73 \mathrm{~m}^{2} / \text { week + } \\
\text { placebo }\end{array}$ & $53 \%$ (total) & $21 \%$ (total) & $\begin{array}{l}\text { Drug dose } \\
\text { modified (40\%) }\end{array}$ \\
\hline
\end{tabular}

Abbreviations: ALT, alanine transaminase; HCV, hepatitis C virus; IFN, interferon; SVR, sustained viral response; NA, not available; $n$, number of subjects; G, genotype; d/c. discontinued; $\mathrm{CHC}$, chronic hepatitis $\mathrm{C}$.

Side effects attributed to ribavirin include nausea, skin rash, cough, and shortness of breath. Hemolytic anemia is one of its most commonly observed effects, which is dose-dependent and does not usually require drug discontinuation (average decrease in hemoglobin of $2-3 \mathrm{~g}$ ). ${ }^{13}$ There are reports of teratogenic and embryotoxic effects of ribavirin in animal studies that have raised concerns about the use of this medication in males and females with reproductive potential, ${ }^{58}$ and hence sexually active patients should be advised to use appropriate contraceptive methods during treatment and for 6 months thereafter.

The recommended laboratory tests to be monitored during therapy, according to the NASPGHAN practice guidelines, are summarized in Table 4. These include complete blood cell count and absolute neutrophil count, an hepatic panel, and glucose, thyroid-stimulating hormone, urine human chorionic gonadotropin (for female patients 13 years of age and older), prothrombin time, urinalysis, and HCV RNA. ${ }^{28}$

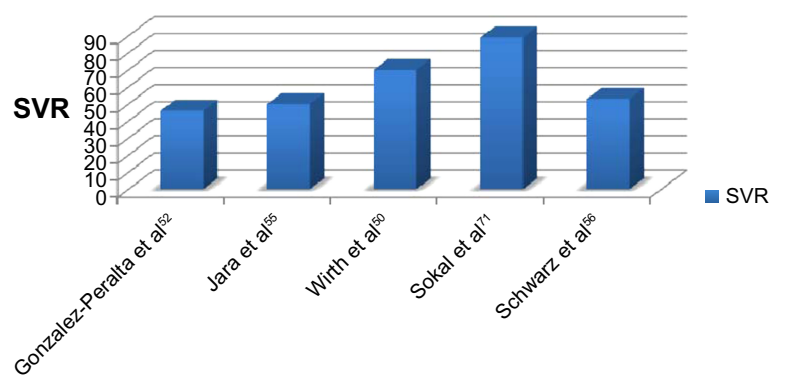

Figure 2 Comparison of sustained viral response (SVR) of recent studies on management of hepatitis $C$ in children.
Isolated case reports raised concern about central nervous system toxicity because of the use of IFN in infants. ${ }^{36,59}$ Also, ribavirin has been found to have teratogenic and embryotoxic effects in animal studies, ${ }^{13}$ requiring girls of reproductive age to agree to be placed on birth control if treatment is initiated.

There are limited pediatric data on patients with chronic hepatitis $\mathrm{C}$ and other comorbid conditions more commonly seen in adults, but it is important to be aware of the special care required should such a pediatric patient be encountered. For example, patients with end-stage renal disease on dialysis require close monitoring as they do not tolerate ribavirin well and often require monotherapy with IFN. In adult studies, post-renal transplant HCV therapy is generally not recommended because of concerns regarding the risk of

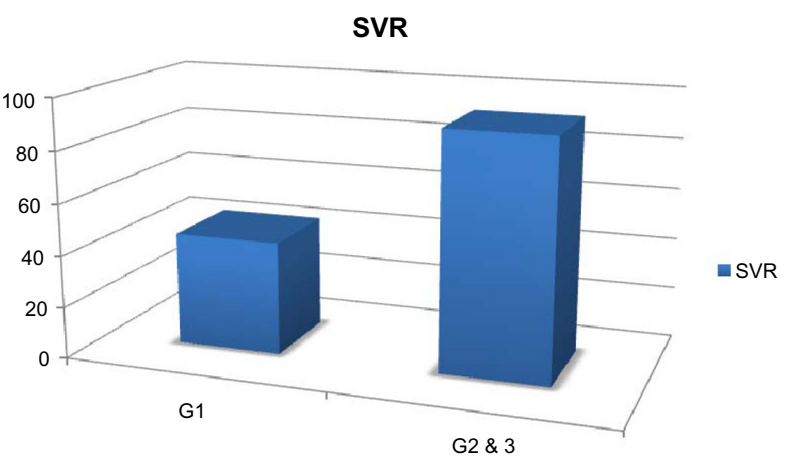

Figure 3 Sustained viral response comparing patients treated with PEGylatedinterferon and ribavarin combination therapy with genotype I versus genotypes 2 and 3 .

Abbreviations: SVR, sustained viral response; GI, genotype I; G2\&3, genotypes 2 and 3 . 
Table 4 Timetable for laboratory monitoring during treatment for $\mathrm{HCV}$ infection

\begin{tabular}{ll}
\hline Laboratory test & $\begin{array}{l}\text { Frequency of testing } \\
\text { in weeks }\end{array}$ \\
\hline CBC & $0,1,2,4,8,12$ and then \\
every $4-8$ weeks \\
$0,1,2,4,8,12$ and then \\
Aminotransferases & $0,12,24,36,48$ \\
TFT & $0,4,12,24,48,72$ \\
HCV RNA & 0, repeat if condition changes \\
PT/albumin/bilirubin & 0,24 \\
Urine HCG for girls $>13$ years & 0 \\
Urinalysis & TFT
\end{tabular}

Abbreviations: $\mathrm{CBC}$, complete blood count; TFT, thyroid function test; $\mathrm{HCV}$, hepatitis C virus; PT, prothrombin time; HCG, human chorionic gonadotropin; RNA, ribonucleic acid.

precipitating acute rejection. ${ }^{60}$ However, prophylactic treatment early after liver transplantation is initiated because recurrent hepatitis $\mathrm{C}$ following liver transplantation is a universal phenomenon and graft reinfection with allograft cirrhosis and decompensation occurs rapidly in many patients. ${ }^{61}$

\section{Development of future treatments: direct-acting antivirals}

Currently, research is orientated to the development and approval of direct-acting antiviral agents regulated within the Center for Drug Evaluation and Research at the FDA for the treatment of chronic hepatitis C. Direct-acting antiviral agents interfere with specific steps in the HCV replication cycle through a direct interaction with the $\mathrm{HCV}$ polyprotein and its cleavage products. ${ }^{62}$

The addition of protease inhibitors to PEG-IFN and ribavirin now represents standard therapy in the management of hepatitis $\mathrm{C}$ infection. When used in combination with PEG-IFN and ribavirin, these drugs greatly improve the sustained virologic response in both treatment-naïve adults and among infected adults who have had previous treatment failures. In one study of 520 treatment-naïve patients undertaken in 67 sites in the USA, Canada, and Europe, the sustained virologic response rate was increased to $75 \%$ with addition of a protease inhibitor to standard treatment with PEG-IFN and ribavirin after a 4-week leadin, from $38 \%$ in those receiving standard therapy alone. ${ }^{63}$ In 2011, based on the strong evidence of superiority of this combination, the FDA approved boceprevir and telaprevir for the treatment of adults with chronic hepatitis C. In the multicenter, double-blind, placebo-controlled PILLAR trial (ClinicalTrials.gov identifier NCT00882908), adult patients receiving once-daily simeprevir in addition to PEG-IFN and ribavirin for 24 weeks achieved a $74.7 \%-86.1 \%$ sustained virologic response rate as compared with a $64.9 \%$ sustained virologic response among controls receiving only PEG-IFN and ribavirin. ${ }^{64}$ Similar results were observed among adults who had failed prior therapies, with those in the simeprevir group achieving a $61 \%-80 \%$ sustained virologic response rate as compared with $23 \%$ among those treated with only PEG-IFN and ribavirin. ${ }^{65}$ On November 22, 2013, the FDA approved simeprevir in combination with PEG-IFN and ribavirin as part of a new triple therapy for treatment-naïve and treatment-experienced adults with chronic hepatitis $\mathrm{C}$ infection and compensated liver disease. Currently, multicenter trials are underway to evaluate the safety and efficacy of boceprevir and telaprevir in combination with PEG-IFN and ribavirin among $\mathrm{HCV}$-infected children but the data are not presently available. Nevertheless, it is expected that, as in adults, children will demonstrate substantial increases in sustained virologic response rates with triple therapy.

On December 6, 2013, the FDA approved sofosbuvir, a polymerase inhibitor, for use in adults with chronic hepatitis C. ${ }^{66}$ Sofosbuvir is used for the treatment of chronic hepatitis $\mathrm{C}$ in combination with PEG-IFN and ribavirin in patients with HCV genotypes 1 and 4 or with ribavirin alone in patients with $\mathrm{HCV}$ genotypes 2 and 3. It is also used in $\mathrm{HCV}$ patients with HIV coinfection. Polymerase inhibitors have been shown to have a high barrier to resistance and appear to be effective across a broad range of genotypes, as opposed to protease inhibitors that are more prone to generation of drug-resistant mutations. ${ }^{67}$ The polymerase inhibitors were generally well tolerated as dual therapy, without serious reported adverse events. ${ }^{68}$ Polymerase inhibitors have not been tested in children and are not approved for pediatric use to date.

\section{Extrahepatic disorders associated with $\mathrm{HCV}$ infection}

In children, extrahepatic manifestations (articular, skin, and hematologic disorders) in chronic hepatitis $\mathrm{C}$ infection are less common than in adults. $\mathrm{HCV}$ infection may elicit autoimmune reactions resulting in generalized deposition of immune complexes and lymphoproliferative disorders, such as glomerulonephritis and cutaneous vasculitis. ${ }^{69}$ In certain cases, IFN therapy can trigger those manifestations with an immune mechanism. Less well documented disorders associated with HCV infection include non-Hodgkin's lymphoma, thrombocytopenia, sialadenitis, thyroid disease, lichen 
planus, porphyria cutanea tarda, rheumatoid disorders, and neurological disorders. In the authors' experience, several cases of patients developing thyroiditis while on antiviral therapy have been observed. Thus, evaluation of autoimmune markers is recommended prior to initiation of antiviral therapy. Specifically, screening HCV-infected patients with thyroid function tests is recommended. ${ }^{70}$

\section{Conclusion}

$\mathrm{HCV}$ infection is a worldwide health care problem affecting millions of adults and children. Appropriate management of this infection starts with screening and identification of patients at risk, which in turn facilitates treatment decisions for infected patients and provides opportunities to prevent further spread of the disease. Although public attention has not focused on pediatric $\mathrm{HCV}$ in the past, this infection has a significant impact on the lives of HCV-infected children and their families. Furthermore, HCV infection in the young plays a crucial role in the spread of this disease to the public at large. The natural history of HCV infection in children has not been clearly established, and the decision to initiate medical treatment should take into consideration a number of important factors, with patient and family education as a key component of management. Increased awareness and surveillance of HCV infection has been called for by the Institute of Medicine. Unfortunately, there are insufficient data involving the pediatric population, so our understanding of the epidemiology, natural history, and response to treatment is limited. Further investigations are needed to expand our knowledge about this infection and to prevent associated morbidity and mortality.

\section{Disclosure}

The authors report no conflicts of interest in this work.

\section{References}

1. Mohd Hanafiah K, Groeger J, Flaxman AD, Wiersma ST. Global epidemiology of hepatitis $\mathrm{C}$ virus infection: new estimates of agespecific antibody to HCV seroprevalence. Hepatology. 2013;57(4): 1333-1342.

2. Colvin HM, Mitchell AE. Institute of Medicine of the National Academies. Hepatitis and liver cancer: a national strategy for prevention and control of hepatitis B and C. Available from: http://www.iom.edu/ Reports/2010/Hepatitis-and-Liver-Cancer-A-National-Strategy-forPrevention-and-Control-of-Hepatitis-B-and-C.aspx. Accessed May 13, 2014.

3. Alter MJ, Kruszon-Moran D, Nainan OV, et al. The prevalence of hepatitis C virus infection in the United States, 1988 through 1994. N Engl J Med. 1999;341(8):556-562.

4. Jhaveri R, Grant W, Kauf TL, McHutchison J. The burden of hepatitis C virus infection in children: estimated direct medical costs over a 10-year period. J Pediatr. 2006;148(3):353-358.
5. Bortolotti F, Resti M, Giacchino R, et al. Changing epidemiologic pattern of chronic hepatitis $\mathrm{C}$ virus infection in Italian children. J Pediatr. 1998;133(3):378-381.

6. Mohan N, Gonzales-Peralta RP, Fujisawa T, et al. Chronic hepatitis C virus infection in children. $J$ Pediatr Gastroenterol Nutr. 2010;50(2):123-131.

7. Shiraki K, Ohto H, Inaba N, et al. Guidelines for care of pregnant women carrying hepatitis $\mathrm{C}$ virus and their infants. Pediatr Int. 2008;50(1):138-140.

8. Conte D, Fraquelli M, Prati D, Colucci A, Minola E. Prevalence and clinical course of chronic hepatitis $\mathrm{C}$ virus (HCV) infection and rate of $\mathrm{HCV}$ vertical transmission in a cohort of 15,250 pregnant women. Hepatology. 2000;31(3):751-755.

9. Ceci O, Margiotta M, Marello F, et al. Vertical transmission of hepatitis $\mathrm{C}$ virus in a cohort of 2,447 HIV-seronegative pregnant women: a 24-month prospective study. J Pediatr Gastroenterol Nutr. 2001;33(5):570-575.

10. Tovo PA, Palomba E, Ferraris G, et al. Increased risk of maternalinfant hepatitis $\mathrm{C}$ virus transmission for women coinfected with human immunodeficiency virus type 1. Italian Study Group for HCV Infection in Children. Clin Infect Dis. 1997;25(5):1121-1124.

11. Delgado-Borrego A, Smith L, Jonas MM, et al. Expected and actual case ascertainment and treatment rates for children infected with hepatitis $\mathrm{C}$ in Florida and the United States: epidemiologic evidence from statewide and nationwide surveys. J Pediatr. 2012;161(5):915-921.

12. González-Peralta RP, Langham MR Jr, Andres JM, et al. Hepatocellular carcinoma in 2 young adolescents with chronic hepatitis C. J Pediatr Gastroenterol Nutr. 2009;48(5):630-635.

13. Karnsakul W, Alford MK, Schwarz KB. Managing pediatric hepatitis C: current and emerging treatment options. Ther Clin Risk Manag. 2009;5(3):651-660.

14. Lavanchy D. The global burden of hepatitis C. Liver Int. 2009; 29 Suppl 1:74-81.

15. Davison SM, Mieli-Vergani G, Sira J, Kelly DA. Perinatal hepatitis C virus infection: diagnosis and management. Arch Dis Child. 2006;91(9):781-785.

16. Bortolotti $\mathrm{F}$, Verucchi $\mathrm{G}, \mathrm{Cammà} \mathrm{C}$, et al. Long-term course of chronic hepatitis $\mathrm{C}$ in children: from viral clearance to end-stage liver disease. Gastroenterology. 2008;134(7):1900-1907.

17. Yeung LT, To T, King SM, Roberts EA. Spontaneous clearance of childhood hepatitis C virus infection. J Viral Hepat. 2007;14(11): 797-805.

18. Bortolotti F, Resti M, Marcellini M, et al. Hepatitis C virus (HCV) genotypes in 373 Italian children with HCV infection: changing distribution and correlation with clinical features and outcome. Gut. 2005;54(6):852-857.

19. Wirth S. Current treatment options and response rates in children with chronic hepatitis C. World J Gastroenterol. 2012;18(2):99-104.

20. Pawlowska M, Pilarczyk M, Foksinska A, Smukalska E, Halota W. Hematological adverse events and sustained viral response in children undergoing therapy for chronic hepatitis C infection. Hepat Mon. 2011;11(12):968-974.

21. Badizadegan K, Jonas MM, Ott MJ, Nelson SP, Perez-Atayde AR. Histopathology of the liver in children with chronic hepatitis $\mathrm{C}$ viral infection. Hepatology. 1998;28(5):1416-1423.

22. El-Hawary MA, El-Raziky MS, Esmat G, et al. Assessment of hepatic fibrosis in pediatric cases with hepatitis C virus in Egypt. World $J$ Gastroenterol. 2007;13(20):2846-2851.

23. Goodman ZD, Makhlouf HR, Liu L, et al. Pathology of chronic hepatitis C in children: liver biopsy findings in the Peds-C Trial. Hepatology. 2008;47(3):836-843.

24. Rodrigue JR, Balistreri W, Haber B, et al. Impact of hepatitis C virus infection on children and their caregivers: quality of life, cognitive, and emotional outcomes. J Pediatr Gastroenterol Nutr. 2009;48(3):341-347.

25. Centers for Disease Control and Prevention. Hepatitis C FAQs for Health Professionals. Available from: http://www.cdc.gov/hepatitis/ HCV/HCVfaq.htm\#section3. Accessed May 13, 2014. 
26. Tohme RA, Holmberg SD. Is sexual contact a major mode of hepatitis $\mathrm{C}$ virus transmission? Hepatology. 2010;52(4):1497-1505.

27. Centers for Disease Control and Prevention. Hepatitis $\mathrm{C}$ virus infection among adolescents and young adults - Massachusetts, 2002-2009. Morbidity and Mortality Weekly Report. Available from: http://www. cdc.gov/mmwr/preview/mmwrhtml/mm6017a2.htm. Accessed May 14, 2014.

28. Mack CL, Gonzalez-Peralta RP, Gupta N, et al. NASPGHAN practice guidelines: diagnosis and management of hepatitis $\mathrm{C}$ infection in infants, children, and adolescents. J Pediatr Gastroenterol Nutr. 2012;54(6):838-955.

29. Indolfi G, Mangone G, Bartolini E, et al. Comparative analysis of rs12979860 SNP of the IFNL3 gene in children with hepatitis C and ethnic matched controls using 1000 Genomes Project data. PLoS One. 2014;9(1):e85899.

30. Ghany MG, Strader DB, Thomas DL, Seeff LB; American Association for the Study of Liver Diseases. Diagnosis, management, and treatment of hepatitis C: an update. Hepatology. 2009;49(4) 1335-1374.

31. Pawlotsky JM. Use and interpretation of virological tests for hepatitis C. Hepatology. 2002;36(5 Suppl 1):S65-S73.

32. Delgado-Borrego A, Jonas MM. Treatment options for hepatitis C infection in children. Curr Treat Options Gastroenterol. 2004;7(5): 373-379.

33. D'Souza R, Glynn MJ, Ushiro-Lumb I, et al. Prevalence of hepatitis C-related cirrhosis in elderly Asian patients infected in childhood. Clin Gastroenterol Hepatol. 2005;3(9):910-917.

34. Conrad S, Garrett LE, Cooksley WG, Dunne MP, MacDonald GA. Living with chronic hepatitis $\mathrm{C}$ means 'you just haven't got a normal life any more'. Chronic Illn. 2006;2(2):121-131.

35. Wirth S, Pieper-Boustani H, Lang T, et al. PEGinterferon alfa- $2 \mathrm{~b}$ plus ribavirin treatment in children and adolescents with chronic hepatitis C. Hepatology. 2005;41(5):1013-1018.

36. Barlow CF, Priebe CJ, Mulliken JB, et al. Spastic diplegia as a complication of interferon alfa-2a treatment of hemangiomas of infancy. J Pediatr. 1998;132(3 Pt 1):527-530.

37. Mohan P, Barton BA, Narkewicz MR, et al. Evaluating progression of liver disease from repeat liver biopsies in children with chronic hepatitis $\mathrm{C}$ : a retrospective study. Hepatology. 2013;58(5):1580-1586.

38. Donato F, Boffetta P, Puoti M. A meta-analysis of epidemiological studies on the combined effect of hepatitis $\mathrm{B}$ and $\mathrm{C}$ virus infections in causing hepatocellular carcinoma. Int J Cancer. 1998;75(3): 347-354.

39. Tural C, Galeras JA, Planas R, et al. Differences in virological response to pegylated interferon and ribavirin between hepatitis $\mathrm{C}$ virus (HCV)-monoinfected and HCV-HIV-coinfected patients. Antivir Ther. 2008;13(8):1047-1055.

40. Yoon EJ, Hu KQ. Hepatitis C virus (HCV) infection and hepatic steatosis. Int J Med Sci. 2006;3(2):53-56.

41. Loomba R, Rivera MM, McBurney R, et al. The natural history of acute hepatitis C: clinical presentation, laboratory findings and treatment outcomes. Aliment Pharmacol Ther. 2011;33(5):559-565.

42. Martinot-Peignoux M, Maylin S, Moucari R, et al. Virological response at 4 weeks to predict outcome of hepatitis $C$ treatment with PEGylated interferon and ribavirin. Antivir Ther. 2009;14(4):501-511.

43. Yu JW, Wang GQ, Sun LJ, Li XG, Li SC. Predictive value of rapid virological response and early virological response on sustained virological response in HCV patients treated with PEGylated interferon alpha-2a and ribavirin. $J$ Gastroenterol Hepatol. 2007;22(6): 832-836.

44. Poordad F, Reddy KR, Martin P. Rapid virologic response: a new milestone in the management of chronic hepatitis C. Clin Infect Dis. 2008;46(1):78-84

45. Davis GL, Wong JB, McHutchison JG, Manns MP, Harvey J, Albrecht J. Early virologic response to treatment with peginterferon alfa- $2 \mathrm{~b}$ plus ribavirin in patients with chronic hepatitis C. Hepatology. 2003;38(3):645-652.
46. Davis GL, Esteban-Mur R, Rustgi V, et al. Interferon alfa-2b alone or in combination with ribavirin for the treatment of relapse of chronic hepatitis C. International Hepatitis Interventional Therapy Group. N Engl J Med. 1998;339(21):1493-1499.

47. McHutchison JG, Gordon SC, Schiff ER, et al. Interferon alfa-2b alone or in combination with ribavirin as initial treatment for chronic hepatitis C. Hepatitis Interventional Therapy Group. $N$ Engl J Med. 1998;339(21):1485-1492.

48. Di Bisceglie AM, Ghalib RH, Hamzeh FM, Rustgi VK. Early virologic response after peginterferon alpha-2a plus ribavirin or peginterferon alpha-2b plus ribavirin treatment in patients with chronic hepatitis $\mathrm{C}$. J Viral Hepat. 2007;14(10):721-729.

49. Schwarz KB, Mohan P, Narkewicz M, et al. Peginterferon with or without ribavirin for chronic hepatitis $\mathrm{C}$ in children and adolescents: final results of the Peds-C trial. Hepatology. 2008;48: 418A.

50. Wirth S, Ribes-Koninckx C, Calzado MA, et al. High sustained virologic response rates in children with chronic hepatitis $\mathrm{C}$ receiving peginterferon alfa-2b plus ribavirin. $J$ Hepatol. 2010;52(4): 501-507.

51. Jacobson IM, Gonzalez SA, Ahmed F, et al. A randomized trial of pegylated interferon alpha- $2 \mathrm{~b}$ plus ribavirin in the retreatment of chronic hepatitis C. Am J Gastroenterol. 2005;100(11):2453-2462.

52. González-Peralta RP, Kelly DA, Haber B, et al. Interferon alfa- $2 b$ in combination with ribavirin for the treatment of chronic hepatitis $\mathrm{C}$ in children: efficacy, safety, and pharmacokinetics. Hepatology. 2005;42(5):1010-1018.

53. Delgado-Borrego A, Healey D, Negre B, et al. Influence of body mass index on outcome of pediatric chronic hepatitis $\mathrm{C}$ virus infection. J Pediatr Gastroenterol Nutr. 2010;51(2):191-197.

54. Mangia A, Thompson AJ, Santoro R, et al. An IL28B polymorphism determines treatment response of hepatitis $\mathrm{C}$ virus genotype 2 or 3 patients who do not achieve a rapid virologic response. Gastroenterology. 2010;139(3):821-827. e1.

55. Jara $\mathrm{P}$, Hierro L, de la Vega A, et al. Efficacy and safety of peginterferonalpha $2 \mathrm{~b}$ and ribavirin combination therapy in children with chronic hepatitis C infection. Pediatr Infect Dis J. 2008;27(2):142-148.

56. Schwarz KB, Gonzalez-Peralta RP, Murray KF, et al. The combination of ribavirin and peginterferon is superior to peginterferon and placebo for children and adolescents with chronic hepatitis C. Gastroenterology. 2011;140(2):450-458. e1.

57. Schwarz K, Gonzalez-Peralta RP, Murray KF, et al. Peginterferon with or without ribavirin for chronic hepatitis $\mathrm{C}$ in children and adolescents: final results of the PEDS-C trial. Hepatology. 2008;48:418A.

58. Krilov LR. Safety issues related to the administration of ribavirin. Pediatr Infect Dis J. 2002;21(5):479-481.

59. Miller VS, Zwiener RJ, Fielman BA. Interferon-associated refractory status epilepticus. Pediatrics. 1994;93(3):511-512.

60. Morales JM, Aguado JM. Hepatitis C and renal transplantation. Curr Opin Organ Transplant. 2012;17(6):609-615.

61. Gordon FD, Kwo P, Vargas HE. Treatment of hepatitis C in liver transplant recipients. Liver Transpl. 2009;15(2):126-135.

62. US Department of Health and Human Services. Food and Drug Administration Center for Drug Evaluation and Research. Guidance for industry chronic hepatitis $\mathrm{C}$ virus infection: developing directacting antiviral drugs for treatment. Available from: http://www.fda. gov/downloads/drugs/guidancecomplianceregulatoryinformation/ guidances/ucm225333.pdf. Accessed May 13, 2014.

63. Kwo PY, Lawitz EJ, McCone J, et al. Efficacy of boceprevir, an NS3 protease inhibitor, in combination with peginterferon alfa- $2 b$ and ribavirin in treatment-naive patients with genotype 1 hepatitis $\mathrm{C}$ infection (SPRINT-1): an open-label, randomised, multicentre phase 2 trial. Lancet. 2010;376(9742):705-716.

64. Fried MW, Buti M, Dore GJ, et al. Once-daily simeprevir (TMC435) with pegylated interferon and ribavirin in treatment-naive genotype 1 hepatitis C: the randomized PILLAR study. Hepatology. 2013;58(6): 1918-1929. 
65. Zeuzem S, Berg T, Gane E, et al. Simeprevir increases rate of sustained virologic response among treatment-experienced patients with $\mathrm{HCV}$ genotype-1 infection: a phase iib trial. Gastroenterology. 2014;146(2): 430-441. e6.

66. Pollack A. FDA approves pill to treat hepatitis C. New York Times, 2013. Available from: http://www.nytimes.com/2013/12/07/business/ fda-approves-pill-to-treat-hepatitis-c.html. Accessed May 14, 2014.

67. Alkhouri N, Zein NN. Protease inhibitors: silver bullets for chronic hepatitis C infection? Cleve Clin J Med. 2012;79(3):213-222.

68. Soriano V, Vispo E, de Mendoza C, et al. Hepatitis C therapy with HCV NS5B polymerase inhibitors. Expert Opin Pharmacother. 2013; 14(9):1161-1170
69. Azoicai AN, Moraru E. [Chronic hepatitis C in children: are extrahepatic manifestations an argument for standard therapy?] Rev Med Chir Soc Med Nat Iasi. 2010;114(4):1035-1041. Iranian.

70. Nair Kesavachandran C, Haamann F, Nienhaus A. Frequency of thyroid dysfunctions during interferon alpha treatment of single and combination therapy in hepatitis C virus-infected patients: a systematic review based analysis. PLoS One. 2013;8(2):e55364.

71. Sokal EM, Bourgois A, Stéphenne X, et al. Peginterferon alfa-2a plus ribavirin for chronic hepatitis $\mathrm{C}$ virus infection in children and adolescents. J Hepatol. 2010;52(6):827-831.

\section{Publish your work in this journal}

Pediatric Health, Medicine and Therapeutics is an international, peerreviewed, open access journal publishing original research, reports, editorials, reviews and commentaries. All aspects of health maintenance, preventative measures and disease treatment interventions are addressed within the journal. Practitioners from all disciplines are invited to submit their work as well as healthcare researchers and patient support groups. The manuscript management system is completely online and includes a very quick and fair peer-review system. Visit http://www.dovepress.com/ testimonials.php to read real quotes from published authors.

Submit your manuscript here: http://www.dovepress.com/pediatric-health-medicine-and-therapeutics-journal 